\title{
Transferência de imunidade passiva (TIP) em bezerras alimentadas com colostro de vacas com mastite subclínica
}

Renata Freitas Leite, Camila Costa Baccili, Cynthia Pereira da Costa e Silva, Sylvia Marquart Fontes Novo, Vinicius Alvim Passos Baldacim, Nilson Roberti Benites, Viviani Gomes

Faculdade de Medicina Veterinária e Zootecnia, Universidade de São Paulo (USP), São Paulo, SP, Brasil

*Autor correspondente

e-mail: camila.rcosta@usp.br

\section{Resumo}

Bezerras recém-nascidas são agamaglobulinêmicas ao nascimento, sendo dependentes da ingestão de colostro de boa qualidade para garantir a prevenção de doenças nos primeiros meses de vida. Sabe-se que a mastite bovina é de comum ocorrência no periparto e que diminui a quantidade e qualidade do colostro produzido, devido à menor concentração de imunoglobulinas. Assim, o presente estudo teve como objetivo avaliar a influência da infecção bacteriana da glândula mamária (GM) sobre a transferência de imunidade passiva (TIP) em bezerras recém-nascidas. Vacas holandesas $(n=13)$ foram observadas no momento da parição e amostras de colostro $(n=52)$ foram assepticamente obtidas para a cultura microbiológica em ágar sangue e ágar Sabouraud. Nas primeiras $12 \mathrm{~h}$ de vida, as bezerras recém-nascidas receberam o volume de 6 litros de colostro, dividido em duas mamadas, proveniente da ordenha de todos os quartos mamários de suas respectivas mães. Amostras de sangue foram colhidas desses animais antes (D0) e após (D2) o manejo do colostro. Foi feita a avaliação da TIP pelos testes de turbidez em sulfato de zinco, proteína sérica total, albumina, atividade sérica da gama glutamiltransferase, eletroforese e leucograma. As bezerras foram distribuídas em dois grupos, conforme a ausência (IB-) ou presença (IB+) de infecção mamária em pelo menos um quarto mamário de suas respectivas mães. Das treze fêmeas avaliadas, oito (61\%) apresentaram crescimento bacteriano em $\geq 1$ quartos mamários. Considerando-se os quartos mamários, foi obtido isolamento bacteriano em 21,15\% (11/52) e as espécies pertencentes ao grupo Staphylococcus coagulase negativa (SCN) foram as mais predominantes. Nenhuma amostra de colostro $(n=52)$ apresentou crescimento fúngico. Os resultados das avaliações entre os bezerros foram semelhantes $(\mathrm{P}>0,05)$, entretanto foram observadas diferenças entre os tempos $(\mathrm{P}<0,05)$. As bezerras alimentadas com colostro de vacas com infecção mamária apresentaram valores de proteína total, globulinas, atividade sérica da gama glutamiltransferase e frações eletroforéticas beta e gamaglobulina em D0 e D2 de, respectivamente, 4,21 e 6,88 g/dL; 1,41 e 4,43 g/dL; 
4,52 e 334,37 U/L; 0,62 e 1,22 g/dL; 0,21 e 2,49 g/dL. Já as bezerras alimentadas com colostro de vacas com mastite apresentaram valores de proteína total, globulinas, atividade sérica da gama glutamiltransferase e frações eletroforéticas beta e gamaglobulina em D0 e D2 de, respectivamente, 4,13 e 6,61 g/dL; 1,45 e 4,27 $\mathrm{g} / \mathrm{dL} ; 3,83$ e 220,96 U/L; 0,54 e 1,17 g/dL; 0,62 e 2,48 g/dL Os resultados obtidos por estes testes revelaram que a administração de colostro e a absorção das imunoglobulinas pelas bezerras foi adequada, uma vez que não foram encontradas evidências de falhas de transferência de imunidade passiva pelos testes utilizados. 0 estudo concluiu que a mastite subclínica não influencia na transferência de imunidade passiva em bezerros recém-nascidos da raça Holandesa, avaliados por teste bioquímicos, eletroforese e leucograma. 